\title{
Corrigenda
}

Genome Research 27: 757-767 (2017)

\section{Corrigendum: Direct determination of diploid genome sequences}

Neil I. Weisenfeld, Vijay Kumar, Preyas Shah, Deanna M. Church, and David B. Jaffe

The authors would like to correct the omission of Supplemental Notes, which was inadvertently excluded from the initial publication of this article. Please note that the Supplemental Notes have now been published online in the Revised Supplemental Material. The authors apologize for the inconvenience.

doi: $10.1101 /$ gr.235812.118

Genome Research 28: 203-213 (2018)

\section{Corrigendum: Transcription rate strongly affects splicing fidelity and cotranscriptionality} in budding yeast

Vahid Aslanzadeh, Yuanhua Huang, Guido Sanguinetti, and Jean D. Beggs

The authors would like to correct errors in Figures 2, 4, and Supplemental Figure S3, which were inadvertently mislabeled in the initial publication of this article. In Figure 2C, the $y$-axis should read SEF $\left(\log _{10}\right)$. Similarly, in Figure 4, panels A, B, D, E, F, and H (both $x$ - and $y$-axes) and Supplemental Figure S3, $\log _{2}$ should be corrected to $\log _{10}$. This error underrepresents the differences in the data. Please note that the revised panels have now been published online with their respective figures and in the Revised Supplemental Material. The authors apologize for the inconvenience.

doi: $10.1101 /$ gr.236265.118 


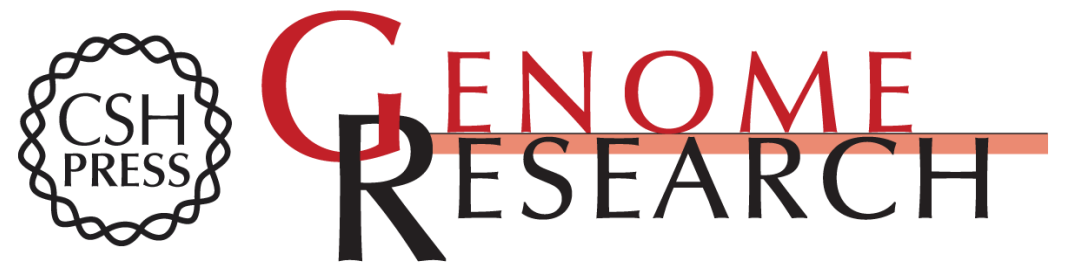

\section{Corrigendum: Direct determination of diploid genome sequences}

Neil I. Weisenfeld, Vijay Kumar, Preyas Shah, et al.

Genome Res. 2018 28: 606.1

Access the most recent version at doi:10.1101/gr.235812.118

\section{Related Content Direct determination of diploid genome sequences}

Neil I. Weisenfeld, Vijay Kumar, Preyas Shah, et al.

Genome Res. May, 2017 27: 757-767

Open Access Freely available online through the Genome Research Open Access option.

\section{License}

Email Alerting Receive free email alerts when new articles cite this article - sign up in the box at the Service top right corner of the article or click here.

\section{Affordable, Accurate Sequencing.}

To subscribe to Genome Research go to: https://genome.cshlp.org/subscriptions 